\begin{tabular}{l}
\hline 56 Of ACCOUnting (JFA) \\
Volume 1, Nomor 1, Juni 2020 \\
P-ISSN: 2722-3132, E-ISSN: 2722-3124 \\
Website: http: pasca-umi.ac.id/index.php/jfa \\
This work is licensed under a Creative Commons Attribution 4.0 International License.
\end{tabular}

\title{
Analisis Persepsi Kegunaan, Kemudahan dan Kerumitan Terhadap Data Pemicu di Approweb Pada Kantor Pelayanan Pajak Pratama
}

\author{
Recky Suhartanto Lawalata ${ }^{1}$, Fadliah Nasaruddin ${ }^{2}$, Ratna Sari ${ }^{3}$ \\ 1,2,3,4 Magister Akuntansi, Universitas Muslim Indonesia. \\ ${ }^{1}$ Koresponden Penulis, E-mail: reckysujartono.lawata@gmail.com
}

\begin{abstract}
ABSTRAK
Penelitian bertujuan untuk menganalisis pengaruh persepsi kegunaan, kemudahan dan kerumitan Technology Acceptance Model (TAM) terhadap data pemicu di approweb, pada Kantor Pelayanan Pajak Pratama Makassar Barat. Penelitian ini menggunakan data primer melalui survei kepada 36 orang responden dari account representative di Kantor Pelayanan Pajak Pratama Makassar Barat. Teknik pengumpulan data melalui kuesioner data dianalisis dengan menggunakan aplikasi SPSS. Pengujian hipotesis menggunakan analisis regresi berganda. Hasil penelitian ini menunjukkan bahwa kebermanfaatan berpengaruh positif dan signifikan sedangkan kemudahan berpengaruh positif tidak signifikan dan kerumitan berpengaruh negatif signifikan terhadap data pemicu di aplikasi approweb. Hasil penelitian ini membuktikan teori TAM dari persepsi kebermanfaatan data pemicu di aplikasi approweb bermanfaat bagi account representative.
\end{abstract}

Kata Kunci: Approweb; Kegunaan; Kemudahan; Kerumitan; Teori TAM

\begin{abstract}
The study aims to analyze the effect of perceived usefulness, ease and complexity of the Technology Acceptance Model (TAM) on trigger data in the Approweb, at the West Makassar Pratama Tax Office. This study uses primary data through a survey of 36 respondents from account representatives at the West Makassar Pratama Tax Office. Data collection techniques through data questionnaires were analyzed using the SPSS application. Hypothesis testing uses multiple regression analysis. The results of this study indicate that usefulness has a positive and significant effect while ease of positive effect is not significant and complexity has a significant negative effect on trigger data in approweb applications. The results of this study prove the TAM theory from the perceived usefulness of trigger data in the approweb application is beneficial for account representatives.
\end{abstract}

Keyword: Approweb; Uses; Convenience; Complexity; TAM theory 
Approweb merupakan sistem aplikasi yang dibuat oleh Direktorat Jenderal Pajak (DJP) untuk membantu Account Representative dalam menyediakan data sebagai bahan baku untuk membuat surat himbauan. Data perpajakan yang bersumber dari data internal dan eksteral dikumpulkan dalam sistem Approweb untuk diolah dan dianalisa apakah sudah sesuai dengan pembayaran pajak yang dilakukan.

Approweb merupakan program berbasis website, aplikasinya berada pada Kantor Pusat Direktorat Jenderal Pajak dan diakses oleh seluruh Account Representative di seluruh Indonesia menggunakan jaringan intranet. Kepala Seksi Pengawasan dan Konsultasi dan Kepala Kantor Pelayanan Pajak dapat mengakses aplikasi tersebut untuk monitoring dan mengawasi penggunaan data dan proses klarifikasi yang dilakukan kepada Wajib Pajak.

Approweb selain digunakan sebagai tempat untuk mengadministrasikan penomoran surat dan softcopy analisa atas himbauan/Surat Permintaan Penjelasan Atas Data dan atau Keterangan (SP2DK), juga digunakan untuk menyimpan softcopy respon atau jawaban tertulis dari Wajib Pajak atas SP2DK yang diterima. Approweb juga digunakan sebagai tempat melihat aktivitas kegiatan penerbitan Surat Tagihan Pajak (STP) serta aktivitas lainnya non penggalian potensi seperti kunjungan kerja, undangan, sosialisasi serta korespondensi.

Salah satu bentuk dari pengawasan kepada Wajib Pajak yang dilakukan oleh Account Representative adalah mengirim surat himbauan kepada Wajib Pajak dengan tujuan mengetahui faktor-faktor penyebab ketidakpatuhan Wajib Pajak, memberikan pelayanan sekaligus pembinaan yang lebih baik kepada Wajib Pajak dan untuk meningkatkan kepatuhan sukarela Wajib Pajak (Hamzah et al., 2018). Sebelum pelaksanaan aktivitas himbauan, terdapat tahap persiapan untuk menentukan Wajib Pajak sasaran dan pengetahuan awal untuk memahami proses bisnis Wajib Pajak yang bersangkutan. Untuk dapat memilih Wajib Pajak sasaran yang tepat, dibutuhkan informasi data pemicu yang akurat sehingga dapat diperkirakan jumlah potensi yang akan diperoleh untuk penerimaan pajak. Data potensi tersebut telah disedikan pada sistem Approweb untuk ditindaklanjuti sebagai data awal. Data tersebut masih harus diolah terlebih dahulu dan diproses lebih lanjut dengan melakukan verifikasi data terhadap SPT yang telah disampaikan oleh Wajib Pajak.

Data pemicu yang ada di Approweb bersumber dari banyak data internal dan eksternal seperti Faktur Pajak Keluaran yang belum disampaikan di SPT PPN, Faktur Pajak Masukan yang belum dilaporkan lawan transaksi, data bukti potong PPh 21/23 yang belum dilaporkan di SPT Tahunan, data Pemberitahuan Ekspor Barang (PEB) dan data Pemberitahuan Impor Barang (PIB). Penyajian Data Pemicu pada Approweb dikelompokkan berdasarkan tahun pajak dan per Wajib Pajak. Account Representative yang mengawasi pelaporan dan pembayaran dari Wajib Pajak, akan melihat data tersebut pada aplikasi Approweb lalu menganalisa lebih lanjut mengenai kebenaran data yang ada di data pemicu dibandingkan dengan terhadap data yang telah disampaikan Wajib Pajak pada Surat Pemberitahuan (SPT).

Rekapitulasi keseluruhan data dari data pemicu dibuat dalam satu tabel yang disebut Total Data Awal. Data ini merupakan gabungan dari seluruh Account 
Representative yang dikelompokkan berdasarkan kode seksi/unit bagian yang mengawasi. Dari setiap data pemicu yang telah dianalisa dan ditindaklanjuti oleh Account Representative, sistem Approweb akan memberi tanda bahwa data pemicu sudah selesai sehingga saldo atas data pemicu yang ditindaklanjuti akan bertambah. Idealnya, jumlah data pemicu yang ditindaklanjuti diupayakan sama atau mendekati dari total jumlah data pemicu yang ada. Artinya bahwa setiap data pemicu yang disediakan sistem, diharapkan keseluruhan data telah diklarifikasi oleh account representative. Apabila terdapat data yang tidak sesuai dengan SPT, account representative akan membuat surat himbauan ke Wajib Pajak untuk klarifikasi data. Melalui approweb, diharapkan bagi Wajib Pajak yang dianggap bermasalah oleh pihak Direktorat Jenderal Pajak melalui data pemicu, dapat segera ditindaklanjuti oleh account representative sehingga memudahkan pekerjaan dalam membuat himbauan. Rekapitulasi data pemicu yang telah disediakan oleh sistem approweb diharapkan dapat membantu para account representative dalam menggali potensi pajak.

Berdasarkan data Approweb di KPP Pratama Makassar Barat tanggal 30 Oktober 2019, diketahui bahwa rekapitulasi jumlah data pemicu dan data yang telah ditindaklanjuti oleh Account Representative adalah sebagai berikut:

Tabel 1. Total data pemicu dan ditindaklanjuti

\begin{tabular}{lcrc}
\hline \multicolumn{1}{c}{ Unit } & $\begin{array}{c}\text { Total Data Awal } \\
(\mathbf{R p})\end{array}$ & $\begin{array}{c}\text { Data telah } \\
\text { Ditindaklanjuti (Rp) }\end{array}$ & $\begin{array}{c}\text { \% } \\
\text { ditindaklanjuti }\end{array}$ \\
\hline $\begin{array}{l}\text { Seksi } \\
\text { dan Konsultasi II }\end{array}$ & 70.658 .059 .738 & 59.654 .737 .900 & $84 \%$ \\
$\begin{array}{l}\text { Seksi Pengawasan } \\
\text { dan Konsultasi III }\end{array}$ & 137.451 .930 .623 & 60.752 .129 .887 & $44 \%$ \\
$\begin{array}{l}\text { Seksi Pengawasan } \\
\text { dan Konsultasi IV }\end{array}$ & 86.233 .836 .864 & 64.049 .254 .468 & $74 \%$ \\
$\begin{array}{l}\text { Seksi Ekstensifikasi } \\
\text { dan Penyuluhan }\end{array}$ & 2.993 .104 .411 & 1.562 .147 .244 & $52 \%$ \\
Jumlah & 297.336 .931 .636 & 186.018 .269 .499 & $63 \%$ \\
\hline
\end{tabular}

Sumber: KPP Pratama Makassar Barat (2019)

Berdasarkan tabel 1, diketahui bahwa total persentase tindaklanjut data dari data pemicu yang ada pada Approweb adalah 63\%. Sistem Approweb yang diharapkan dapat membantu Account Representative dalam membuat dan menganalisa data, ternyata tidak semua dimanfaatkan oleh account representative dengan baik. Aplikasi yang telah dibuat dengan tujuan membantu pekerjaan pegawai menjadi lebih mudah tetapi dalam kenyataannya, tidak dijadikan sebagai bahan utama dalam penggalian potensi pajak. Dari data tersebut, persentase penyelesaian tertinggi berada di Seksi Pengawasan dan Konsultasi II senilai $84 \%$ sedangkan persentase penyelesaian terendah berada di Seksi Pengawasan dan Konsultasi III senilai $44 \%$. Perlu dilakukan penelitian tentang penyebab jarak persentase penyelesaian yang cukup jauh dari $44 \%$ ke $84 \%$. Apa yang menyebabkan Seksi Pengawasan dan Konsultasi II dapat menyelesaikan jumlah data pemicu yang ada dengan baik sedangkan mayoritas kegiatan usaha Wajib Pajak pada Kantor Pelayanan Pajak Pratama Makassar Barat adalah di klasifikasi lapangan usaha perdagangan dan 
tersebar merata di seluruh pengawasan konsultasi yang sama. Melalui data tersebut, dapat diambil kesimpulan bahwa sistem yang ada saat ini, masih belum cukup membantu tugas account representative dalam mendeteksi dengan cepat Wajib Pajak yang dianggap bermasalah. Jumlah total data pemicu yang tersedia, masih $63 \%$ yang telah ditindaklanjuti, dengan demikian melalui penyediaan data pemicu di approweb, belum memudahkan pekerjaan yang dilakukan oleh para account representative dalam membuat surat himbauan. Aplikasi data pemicu yang diharapkan mampu memberikan kecepatan pengolahan data ternyata masih belum menjadi prioritas yang dilakukan untuk menggali potensi perpajakan. Davis, (1989), mengemukakan Technology Acceptance Model (TAM) memiliki konstruk utama, yaitu perceived usefulness dan perceived ease of use Perceived usefulness adalah kebermanfaatan sistem teknologi informasi yang dipersepsikan oleh pengguna dalam meningkatkan kinerjanya, sedangkan perceived ease of use adalah kemudahan penggunaan sistem teknologi informasi yang dipersepsikan oleh pengguna. Amoroso dan Gardner (2004) menambahkan beberapa konstruk eksternal dalam Technology Acceptance Model (TAM) yaitu jenis kelamin (gender), pengalaman (experience), kerumitan (complexity), dan kesukarelaan (voluntariness).

Beberapa penelitian terdahulu memilki keterkaitan dengan konsep penelitian ini yakni berkaitan tentang konsep TAM seperti (Fatmasari \& Ariandi, 2017), (Sayekti \& Putarta, 2016), (Satrio, Su'un, \& Rahim, 2016), (Afriani, Respati \& Kusumawati (2016), (Priyambada, Kusyanti \& Herlambang, 2018), (Putra, 2017). Technology Acceptance Model (TAM) dalam penelitian ini digunakan sebagai dasar hipotesis pertama dan hipotesis kedua bahwa persepsi terhadap kegunaan perceived usefulness) dan Persepsi kemudahan penggunaan teknologi informasi (perceived ease of use) mempengaruhi sikap (attitude) individu terhadap penggunaan Teknologi Informasi, yang selanjutnya akan menentukan apakah individu berniat untuk menggunakan teknologi informasi (intention). Niat untuk menggunakan teknologi informasi akan menentukan apakah individu akan menggunakan teknologi informasi (behavior). Intensitas termasuk ke dalam behavior, yaitu pada saat individu menggunakan teknologi informasi tersebut dan memutuskan untuk terus menggunakannya maka itulah yang dikatakan intensitas penggunaan teknologi informasi.

Setelah kedua faktor tersebut terdapat faktor eksternal lainnya dari Model TAM yaitu kerumitan. (Davis \& Vankatesh, 1996), (Jogiyanto, 2007) mengukur kerumitan ini dalam bentuk waktu yang dihabiskan untuk melakukan tugas-tugas, integritas dari hasil komputer kedalam pekerjaan yang sedang dilakukan. Berdasarkan penjelasan singkat di atas, digambarkan model penelitian sebagaimana tampilan pada gambar 1 . 


\section{Gambar 1. Model Penelitian}

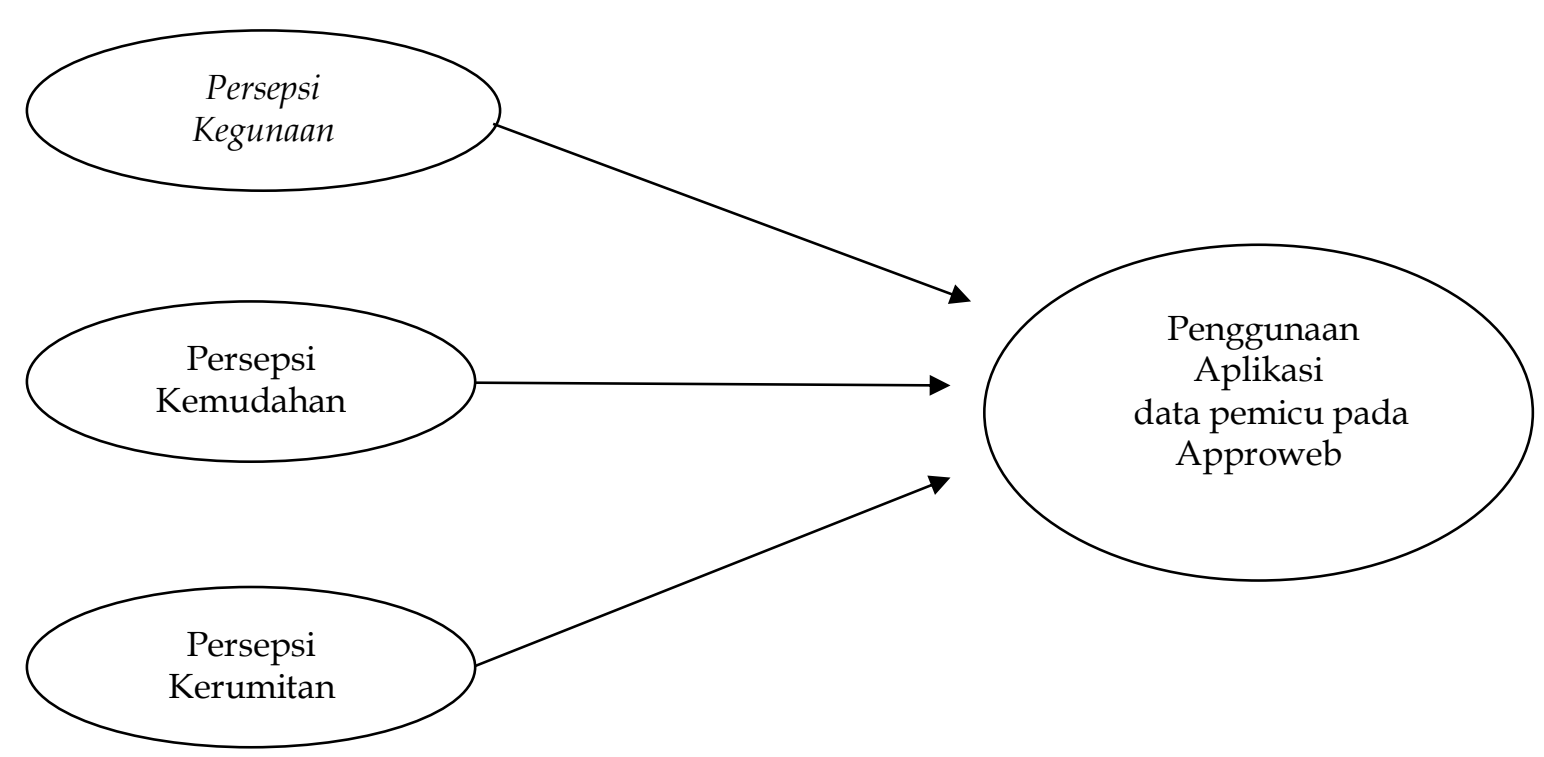

H1 : Persepsi kegunaan (perceived usefulness) berpengaruh positif terhadap penggunaan data pemicu di aplikasi approweb.

H2 : Persepsi kemudahan (perceived ease of use) berpengaruh positif terhadap penggunaan data pemicu di aplikasi approweb

H3 : Persepsi Kerumitan (complexity) berpengaruh negatif terhadap penggunaan data pemicu di aplikasi approweb.

Penelitian ini termasuk penelitian kuantitatif. Penelitian ini dilaksanakan pada Kantor Pelayanan Pajak Pratama Makassar Barat dengan objek penelitian yaitu Account Representative (AR). Pengumpulan data dalam penelitian ini mmenggunakan metode peyebaran juesioner kepada responden penelitian yang berjumlah 36 orang. Data yang berhasil dikumpulkan akan diuji tingkat validtas, reliabilitas dan normalitsnya. Setelah itu akan dilakukan analisis uji multikolinearitas dan heterokedastisitas. Untuk menguji dan menganalisis hipotesis yang diajukan dalam penelitian ini, metode yang digunakan adalah dengan melakukan analisis regresi breganda dengan menggunakan rumus persamaan sebagai berikut:

$Y=\beta_{0}+\beta_{1} X_{1}+\beta_{2} X_{2}+\beta_{3} X_{3}$

Dimana:

$\mathrm{Y}=$ aplikasi data pemicu pada approweb (variabel dependen)

$\beta_{0}=$ konstanta

$\beta_{1}, \beta_{2}, \beta_{3}=$ koefisien regresi

$\mathrm{X}_{1}=$ Persepsi kemudahan penggunaan terhadap penggunaan teknologi

$\mathrm{X}_{2}=$ Persepsi kegunaan penggunaan terhadap penggunaan teknologi 
$\mathrm{X}_{3}=$ Persepsi kerumitan penggunaan terhadap penggunaan teknologi

$\varepsilon=$ error

(Sugiyono, 2010) menjelaskan bahwa untuk mengetahui pengaruh masing-masing variabel exogenous terhadap variabel endogenous dapat menggunakan Uji t dengan melihat besarnya probabilitas value ( $p$ value) dibandingkan dengan 0.05 (Taraf signifikansi $\alpha=5 \%$ ). Kriteria pengujian yang digunakan adalah jika $p$ value $>0.05$ maka $\mathrm{H} 1$ ditolak dan sebaliknya Jika $\mathrm{p}$ value $<0.05$ maka H1 diterima. Lebih lanjut (Sugiyono, 2010) menjelaskan bahwa untuk mengetahui ada tidaknya pengaruh secara bersama-sama (simultan) variabel-variabel exogenous terhadap variabel endogenous. Selanjutnya untuk menguji uji ketepatan perkiraan menyatakan persentase total varians dan variabel endogenous yang dapat diselesaikan oleh variabel exogenous dalam model dapat menggunakan Uji koefesien determinasi $\left(R^{2}\right)$.

Tabel 2. Matriks operasionalisasi variable

\begin{tabular}{|c|c|c|}
\hline Variabel & Indikator & Skala \\
\hline $\begin{array}{l}\text { Penggunaan } \\
\text { teknologi } \\
\text { sesungguhnya (data } \\
\text { pemicu) }(\mathrm{Y})\end{array}$ & $\begin{array}{ll}\text { 1. } & \text { Penggunaan Sesungguhnya } \\
\text { 2. } & \text { Frekuensi Penggunaan } \\
\text { 3. } & \text { Kepuasan pengguna } \\
& \text { (Sumber : Wibowo :2008) }\end{array}$ & Ordinal \\
\hline $\begin{array}{l}\text { Persepsi Kegunaan } \\
\qquad\left(\mathrm{X}_{1}\right)\end{array}$ & $\begin{array}{l}\text { 1. } \text { Pekerjaan lebih cepat selesai } \\
\text { 2. Meningkatkan kinerja } \\
\text { 3. Meningkatkan produktivitas } \\
\text { 4. Meningkatkan efektifitas kerja } \\
\text { 5. Berguna } \\
\text { (Sumber : Davis :1989) }\end{array}$ & Ordinal \\
\hline $\begin{array}{l}\text { Persepsi Kemudahan } \\
\text { penggunaan }\left(X_{2}\right)\end{array}$ & $\begin{array}{l}\text { 1. Kemudahan sistem untuk dipelajari } \\
\text { 2. Kemudahan sistem untuk dikendalikan } \\
\text { 3. Interaksi dengan sistem yang jelas dan mudah } \\
\text { dimengerti } \\
\text { 4. Mudah terampil mengunakan sistem } \\
\text { 5. Mudah untuk digunakan } \\
\text { (Sumber : Davis :1989) }\end{array}$ & Ordinal \\
\hline Kerumitan $\left(X_{3}\right)$ & $\begin{array}{l}\text { 1. Waktu yang diperlukan untuk menyelesaikan tugas } \\
\text { 2. Penggabungan hasil dari komputer dengan pekerjaan } \\
\text { yang sudah ada } \\
\text { (Sumber : Igbaria:1996) }\end{array}$ & Ordinal \\
\hline
\end{tabular}

Sumber: Data diolah peneliti (2020)

Dalam penelitian ini responden mengisi jawaban yang dianggap paling tepat. Jawaban diukur dengan likert scale yang berdimensi 5 skala yaitu (1) Sangat Tidak Setuju, (2) Tidak Setuju, (3) Kurang Setuju, (4) Setuju, dan (5) Sangat Setuju.

\section{HASIL DAN PEMBAHASAN}

\section{A. Hasil Penelitian}

Jumlah kuesioner yang disebar sebanyak 36 kuesioner dan semuanya berhasil diolah dan dianalisis menggunakan software SPSS. 
Tabel 3. Sampel dan Tingkat Pengembalian

\begin{tabular}{lr}
\hline \multicolumn{1}{c}{ Keterangan } & Persentase \\
\hline Kuesioner yang diedarkan & 36 \\
Kuesioner yang tidak kembali & 0 \\
Kuesioner yang direspon & 36 \\
Kuesioner yang jawabannya tidak lengkap & 0 \\
kuesioner yang digunakan & 36 \\
Tingkat pengembalian kuesioner & $100 \%$ \\
\hline
\end{tabular}

Sumber: Data Olahan (2020)

Rata-rata untuk persepsi kegunaan adalah 19,94 dengan jumlah terendah 14 dan jumlah tertinggi 25, rata-rata untuk persepsi kemudahan adalah 19,50 dengan jumlah terendah 16 dan jumlah tertinggi 25, rata-rata untuk persepsi kerumitan adalah 6,06 dengan jumlah terendah 5 dan jumlah tertinggi 8 .

\section{Tabel 4. Uji Statistik Deskriptif Variabel}

\begin{tabular}{lccccc}
\multicolumn{7}{c}{ Descriptive Statistics } \\
& $N$ & Minimum & Maximum & Mean & $\begin{array}{c}\text { Std. } \\
\text { Deviation }\end{array}$ \\
\hline Persepsi Kegunaan & 36 & 14 & 25 & 19,94 & 2,529 \\
Persepsi Kemudahan & 36 & 16 & 25 & 19,50 & 2,624 \\
Persepsi Kerumitan & 36 & 5 & 8 & 6,06 & 0,984 \\
Persepsi Penggunaan & 36 & 11 & 23 & 17,47 & 2,688
\end{tabular}

(Y)

Valid N (listwise)

36

Sumber: Data Ouput SPSS (2020)

Uji validitas digunakan untuk mengukur valid tidaknya suatu kuesioner. Kuesioner dikatakan valid apabila pertanyaan pada kuesioner mampu untuk mengungkapkan sesuatu yang diukur oleh kuesioner tersebut (Ghozali, 2011). Hasil dari Pearson Correlation pada tabel 5, menunjukkan tingkat signifikansi dari ketiga variabel yaitu Kegunaan, Kemudahan dan Kerumitan < 0,01 (2-tailed). Hal ini berarti adanya kesesuaian antara item-item pertanyaan dalam kuesioner yang digunakan dalam penelitian ini dengan variabel lain yang diukur. Dengan demikian, semua item pertanyaan dalam penelitian ini memenuhi persyaratan untuk digunakan dalam analisis data selanjutnya.

Tabel 5. Hasil Uji Validitas

\begin{tabular}{cccccc}
\hline No & Variabel & $\begin{array}{c}\text { Jumlah } \\
\text { Item }\end{array}$ & $\begin{array}{c}\text { Pearson } \\
\text { Correlation }\end{array}$ & Sig. & Status \\
\hline 1 & Kegunaan $\left(\mathrm{X}_{1}\right)$ & 5 & $0,799-0,835^{* *}$ & 0,000 & Valid \\
2 & Kemudahan $\left(\mathrm{X}_{2}\right)$ & 5 & $0,786-0,762^{* *}$ & 0,000 & Valid \\
3 & Kerumitan $\left(\mathrm{X}_{3}\right)$ & 2 & $0,882-0,884^{* *}$ & 0,000 & Valid \\
4 & $\begin{array}{c}\text { Persepsi } \\
2\end{array}$ & 5 & $0,614-0,779^{* *}$ & 0,000 & Valid \\
\hline
\end{tabular}

Sumber: Data Ouput SPSS (2020) 
Reliabilitas merupakan alat untuk mengukur suatu kuesioner yang merupakan indikator atau konstruk. Suatu variabel dinyatakan reliabel jika memberikan nilai Cronbach Alpha > 0,60 (Ghozali, 2011). Semakin tinggi nilai Cronbach Alpha maka semakin reliabel suatu variabel tersebut. Berdasarkan hasil pada tabel 6, maka dapat dilihat bahwa ketiga variabel yaitu Kegunaan, Kemudahan dan Kerumitan yang digunakan dalam penelitian ini memiliki Cronbach's Alpha di atas 0,60. Artinya, terdapat stabilitas dan konsistensi dimana item-item pernyataan variabel tersebut dapat menilai seberapa konsisten suatu instrumen pengukuran mengukur konsep tertentu yang diukurnya sehingga dengan demikian bisa digunakan dalam analisis lebih lanjut.

Tabel 6. Hasil Uji Reliabilitas

\begin{tabular}{ccccl}
\hline No & Variabel & $\begin{array}{c}\text { Jumlah } \\
\text { Item }\end{array}$ & $\begin{array}{c}\text { Cronbach's } \\
\text { Alpha }\end{array}$ & Status \\
\hline 1 & Kegunaan $\left(\mathrm{X}_{1}\right)$ & 5 & 0,873 & Reliable \\
2 & Kemudahan $\left(\mathrm{X}_{2}\right)$ & 5 & 0,773 & Reliable \\
3 & Kerumitan $\left(\mathrm{X}_{3}\right)$ & 2 & 0,885 & Reliable \\
4 & Persepsi Penggunaan $(\mathrm{Y})$ & 5 & 0,795 & Reliable \\
\hline
\end{tabular}

Sumber: Data Ouput SPSS (2020)

Uji normalitas bertujuan untuk menguji apakah dalam model regresi, variabel pengganggu atau residual memiliki distribusi normal. Grafik histogram pada gambar 2, menunjukkan pola distribusi normal dengan pola distribusi cenderung di tengah, sehingga dapat disimpulkan model regresi memenuhi asumsi normalitas.

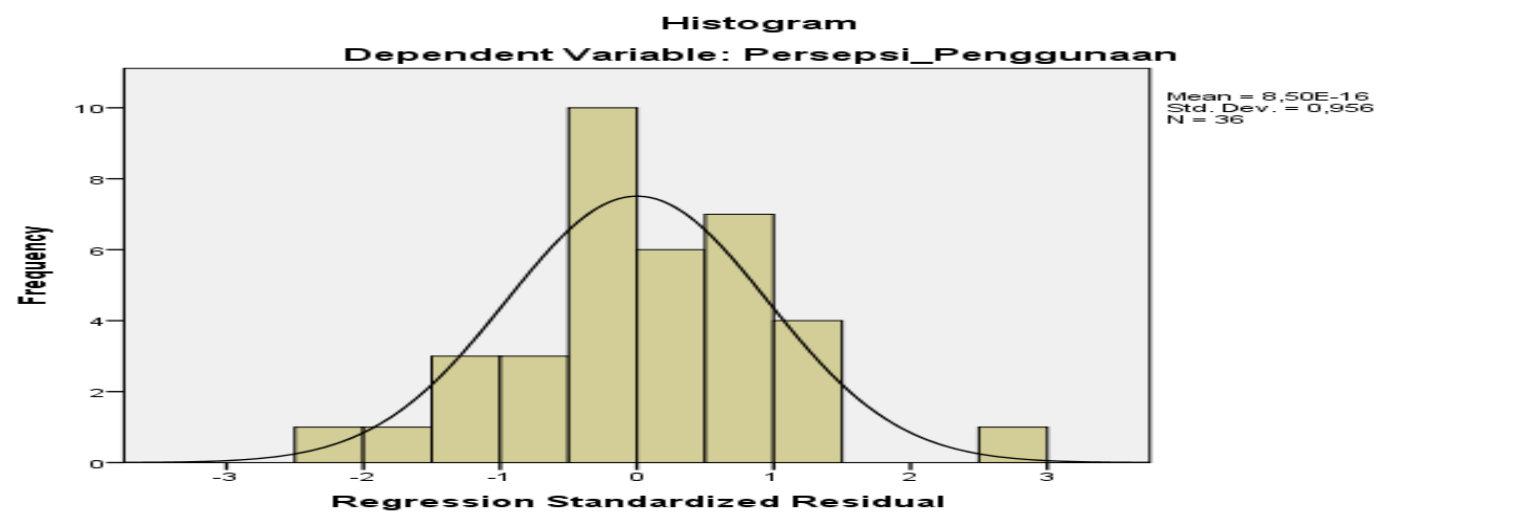

'label '\%. Hasil Uji Heteroskedastisitas

\begin{tabular}{lcc}
\multicolumn{1}{c}{ Variabel } & Sig. & Keterangan \\
\hline Kegunaan & 0,111 & Tidak ada heteroskedastisitas \\
Kemudahan & 0,687 & Tidak ada heteroskedastisitas \\
Kerumitan & 0,642 & Tidak ada heteroskedastisitas \\
\hline
\end{tabular}

Sumber: Data Ouput SPSS (2020)

Uji multikolinieritas bertujuan untuk menguji apakah model regresi ditemukan adanya korelasi antar variabel bebas (independen). Model regresi yang baik seharusnya tidak terjadi korelasi di antara variabel independen (Ghozali, 2011). Uji Multikolinearitas dapat dilakukan dengan melihat VIF (Variance Inflation Factors). Jika VIF < 10 maka tidak terjadi gejala Multikolinearitas. Berdasarkan pengujian statistik pada tabel 8 , hasil uji multikolinearitas menunjukkan bahwa nilai VIF pada 
masing-masing variabel berada pada nilai kurang dari 10. Demikian pula dengan nilai tolerance semua variabel lebih dari 0,01 . Hal ini mengindikasikan bahwa tidak terjadi gejala multikolinearitas pada variabel penelitian.

Tabel 8. Hasil Uji Multikolinearitas

\begin{tabular}{lrrr}
\hline \multicolumn{1}{c}{ Variabel } & Tolerance & VIF & Keterangan \\
\hline Kegunaan & 0,731 & 1,368 & Tidak ada multikolinearitas \\
Kemudahan & 0,718 & 1,393 & Tidak ada multikolinearitas \\
Kerumitan & 0,957 & 1,045 & Tidak ada multikolinearitas \\
\hline
\end{tabular}

Sumber: Data Ouput SPSS (2020)

Berdasarkan tabel 16, dapat dibuat persamaan regresi linear berganda sebagai berikut:

$$
\mathrm{Y}=3,901+0,659 \mathrm{X} 1+0,263 \mathrm{X} 2-0,777 \mathrm{X3}
$$

Secara statistik persamaan regresi tersebut memiliki makna bahwa semakin tinggi pengaruh kegunaan (perceived ease of use), kemudahan (perceived usefullness) dan persepsi kerumitan maka penggunaan data pemicu pada aplikasi approweb akan semakin meningkat.

Tabel 9. Hasil Analisis Regresi Linear Berganda

\begin{tabular}{lrrrrr}
\hline \multirow{1}{*}{ Model } & \multicolumn{2}{c}{$\begin{array}{c}\text { Unstandardized } \\
\text { Coefficients }\end{array}$} & $\begin{array}{c}\text { Standardized } \\
\text { Coefficients }\end{array}$ & \multirow{2}{*}{ T } & \multirow{2}{*}{ Sig. } \\
\cline { 2 - 4 } & \multicolumn{1}{c}{ B } & \multicolumn{1}{c}{$\begin{array}{c}\text { Std. } \\
\text { Error }\end{array}$} & Beta & & \\
\hline Konstanta & 3,901 & 2,938 & & & \\
Kegunaan &, 659 &, 137 &, 620 & 4,328 &, 194 \\
Kemudahan &, 263 &, 133 &, 257 & 1,979 &, 000 \\
Kerumitan &,- 777 &, 307 &,- 284 & $-2,531$ &, 016 \\
\hline
\end{tabular}

Sumber: Data Ouput SPSS (2020)

Koefisien determinasi (R2) pada intinya mengukur seberapa jauh kemampuan model dalam menerangkan variasi variabel dependen. Koefisien determinasi (Adjusted R2) persamaan regresi yang diperoleh berdasarkan table 10 adalah 0,614. Artinya bahwa variabel penggunaan data pemicu di aplikasi approweb dapat dijelaskan oleh variabilitas variabel kegunaan, kemudahaan dan kerumitan sebesar 61,4\% dan selebihnya 38,6\% dijelaskan oleh variabel lain di luar model ini.

Tabel 10. Hasil Uji Koefisien Determinasi

\begin{tabular}{crrrr}
\hline Model & $R$ & $R$ Square & $\begin{array}{c}\text { Adjusted } R \\
\text { Square }\end{array}$ & $\begin{array}{c}\text { Std. Error of the } \\
\text { Estimate }\end{array}$ \\
\hline 1 &, $783^{a}$ &, 614 &, 577 & 1,748
\end{tabular}

Sumber: Data Ouput SPSS (2020)

Uji $\mathrm{F}$ digunakan untuk mengetahui ada tidaknya pengaruh secara bersama-sama (simultan) variabel-variabel eksogen (independen) terhadap variabel endogen (dependen). Uji $\mathrm{F}$ pula dilihat dari besarnya probabilitas value ( $\mathrm{p}$ value) dibandingkan dengan 0,05 (Taraf signifikansi $a=5 \%$ ). 
Tabel 11. Hasil Uji F

ANOVA $^{\text {a }}$

\begin{tabular}{rlrrrrr}
\hline Model & & Sum of & df & Mean Square & F & Sig. \\
& & Squares & & & & \\
\hline \multirow{2}{*}{1} & Regression & 155,203 & 3 & 51,734 & 16,933 &, $000^{\mathrm{b}}$ \\
& Residual & 97,769 & 32 & 3,055 & & \\
& Total & 252,972 & 35 & & & \\
\hline
\end{tabular}

Sumber: Data Ouput SPSS (2020)

Hasil uji $\mathrm{F}$ yang diperoleh pada tabel 11 menunjukkan bahwa nilai signifikansi sebesar 0,000 lebih kecil dari nilai alpha dimana nilai alpha $=0,05$. Dengan demikian dapat disimpulkan bahwa model yang dibangun pada persamaan regresi tersebut memiliki perbedaan yang signifikan.

Pada tabel 9 diperoleh koefisien regresi sebesar 0,659 dan nilai probabilitas signifikansi sebesar 0,000. Probabilitas signifikansi $0,000<$ alpha 0,05 maka secara statistik dapat disimpulkan bahwa variabel kegunaan memiliki pengaruh positif dan signifikan terhadap penggunaan data pemicu di aplikasi approweb. Dengan demikian, hipotesis 1 (diterima).

Pada tabel 9 diperoleh koefisien regresi sebesar 0,263 dan nilai probabilitas signifikansi sebesar 0,056. Probabilitas signifikansi 0,056 > alpha 0,05 maka secara statistik dapat disimpulkan bahwa variabel persepsi kemudahan memiliki pengaruh positif namun tidak signifikan terhadap data pemicu di aplikasi approweb. Dengan demikian, hipotesis 2 (diterima).

Pada tabel 9 diperoleh koefisien regresi sebesar -,777 dan nilai probabilitas signifikansi sebesar 0,016. Probabilitas signifikansi 0,016 < alpha 0,05 maka secara statistik dapat disimpulkan bahwa variabel kerumitan pengaruh negatif dan signifikan terhadap penggunaan data pemicu di aplikasi approweb. Dengan demikian, hipotesis 3 (diterima)

\section{B. Pembahasan}

\section{Persepsi Kegunaan terhadap penggunaan data pemicu di aplikasi approweb.}

Secara statistik hasil penelitian ini menunjkkan bahwa persepsi kegunaan memiliki pengaruh signifikan dan positif terhadap penggunaan data pemicu di aplikasi approweb. Hal ini menunjukkan keselarasan dengan tanggapan responden atas pengukuran tingkat kegunaan cenderung menjawab setuju dan sangat setuju, yang artinya penggunaan data pemicu di approweb dapat memberikan kegunaan dalam mendukung pekerjaannya maka penggunaan data pemicu di aplikasi approweb akan meningkat. Hal ini dibuktikan dengan jawaban responden secara keseluruhan bahwa penggunaan data pemicu pada approweb dapat mempercepat pekerjaan dan akan meningkat kinerja, produktifitas dan berguna dalam pekerjaan account representative dalam penggalian potensi pajak.

Bagi account representative, menggunakan data pemicu pada approweb untuk membuat surat himbauan akan menjadi lebih cepat karena semua data ikhtisar penyandingan data yang mengindikasikan ketidakpatuhan Wajib Pajak baik secara formal maupun material akan ditampilkan secara sistem. Dengan demikian, akan memudahkan pekerjaan dan menghemat waktu dalam bekerja. 
Peningkatan efektivitas pekerjaan account representative dalam penggunaan data pemicu di approweb telah dipersepsikan oleh pengguna dalam melaksanakan pekerjaan. Hal ini tidak terlepas dari waktu yang lebih cepat dalam membuat surat himbauan. Dengan demikian dengan adanya data pemicu, account representative merasa adanya peningkatan kinerja dan produktifitasnya.

Hasil penelitian ini menunjukkan bahwa suatu aplikasi akan diterima oleh account representative apabila merasakan manfaatnya. Penggunaan data pemicu di aplikasi approweb telah dipersepsikan oleh account repesentative sebagai teknologi yang bermanfaat dalam membuat dan menyelesaikan surat himbauan permintaan penjelasan atas data dan/atau keterangan kepada Wajib Pajak. Disamping itu keuntungan yang dirasakan oleh account representative adalah adanya tools atau alat yang dapat langsung menunjukkan data yang harus dilakukan klarifikasi ke Wajib Pajak tanpa harus dilakukan secara manual seperti sebelum menggunakan data pemicu tersebut. Sebelum adanya data pemicu, account representative harus mencari dan menemukan kesalahan yang dilakukan oleh Wajib Pajak dalam menyampaikan SPT melalui penelitian satu per satu atas SPT. Sebagaimana diketahui bahwa dalam sistem self assessment, Wajib Pajak dipercaya untuk menghitung, menyetor dan melaporkan pajak secara mandiri. Hal ini dapat dimanfaatkan oleh beberapa Wajib Pajak untuk tidak melaporkan pajaknya dengan benar melalui cara penghindaran pajak.

Account representative dituntut untuk dapat memahami proses bisnis yang dijalankan oleh Wajib Pajak dan melakukan pengujian terhadap pembayaran dan pelaporan yang telah dilakukan. Analisa laporan keuangan, penyandingan data SPT dengan data pihak ketiga maupun adanya data bukti potong PPh atas kegiatan yang dilakukan, membuat account representative membutuhkan waktu yang cukup banyak untuk menemukan kesalahan apabila dilakukan secara manual tanpa menggunakan sistem. Permasalahan akan semakin kompleks lagi apabila jumlah Wajib Pajak yang dilakukan pengawasan dalam jumlah yang cukup banyak dan data transaksi yang ada lebih dari 1.000 transaksi. Disisi lain, terdapat target ekstra effort yang harus dikumpulkan oleh account representative sebagai capaian kinerja yang telah dilakukan selama ini. Terhadap permasalahan ini, diperlukan cara yang cepat dalam menemukan kesalahan yang dilakukan oleh Wajib Pajak dalam penyampaikan SPT. Melalui data pemicu pada aplikasi approweb, account representative dibantu dengan cepat dalam penyelesaian pekerjaannya. Account representative tidak perlu lagi membuka satu per satu data SPT, melalui sistem data pemicu, kesalahan yang dilakukan oleh Wajib Pajak akan langsung terdeteksi dengan cepat. melalui cara ini, tentu saja akan meningkatkan kinerja bagi rekanrekan account representative sebab output atau keluaran dari hasil pekerjaan berupa surat himbauan, akan dengan cepat dihasilkan dalam waktu yang singkat.

Penelitian ini juga sejalan dengan (Fatmasari \& Ariandi, 2017), (Sayekti \& Putarta, 2016), (Satrio, Su'un \& Rahim, 2016), (Respati \& Kusumawati, 2016), yang membuktikan bahwa kebermanfaatan data pemicu di approweb dianggap penting oleh account representative sehingga berpengaruh positif dan signifikan terhadap sikap pengguna dalam menggunakan sistem data pemicu tersebut.

Persepsi Kemudahan terhadap penggunaan data pemicu di aplikasi approweb. 


\section{7 | Journal of Accounting and Finance (JFA), Vol.1, No. 1, Juni 2020}

Secara statistik hasil penelitian ini menunjukkan bahwa kemudahan penggunaan berpengaruh positif tetapi tidak signifikan terhadap penggunaan data pemicu di approweb. Hal ini berarti persepsi kemudahan dalam penggunaan data pemicu di aplikasi approweb tidak begitu mudah dalam pengoperasiannya. Pengaruh positif dan tidak signifikan terjadi meskipun adanya tanggapan responden cenderung menjawab setuju yang artinya bahwa sebagian account representative mempersepsikan data pemicu secara umum mudah digunakan tetapi tidak terbebas dari upaya dan kendala yang dihadapi dalam penggunaannya di aplikasi approweb.

Persepsi tidak signifikan ini diindikasikan oleh adanya account representative di KPP Pratama Makassar Barat yang menyatakan bahwa meskipun data pemicu mudah digunakan tetapi pihak pengguna dituntut juga berhati-hati dalam menggunakan data pemicu karena apabila terjadi kesalahan penginputan / pemilihan data, maka diperlukan waktu untuk melakukan pembetulan atau pembatalan data yang dimaksud.

Indikasi lain yang dapat terjadi adalah latar belakang pemahaman tentang aturan pajak yang tidak seragam di antara para account representative sehingga tingkat pengoperasian data pemicu pada approweb bervariasi. Untuk dapat memanfaatkan data pemicu, pengalaman penggalian potensi pajak dan analisa laporan keuangan berserta kasus yang dihadapi account representative pada umumnya berbeda yang membuat analisa data bisa membutuhkan waktu antara satu account representative dengan yang lain bisa berbeda. Sehingga walaupun data pemicu tersebut ada di setiap account representative, belum tentu account representative tersebut mudah untuk mengerti dan menggunakan data yang dimaksud dalam menghasilkan surat himbauan. Permasalahan ini tentunya juga membutuhkan banyak usaha serta waktu yang dibutuhkan dalam menganalisa data pemicu tersebut dengan kesesuaiannya terhadap pelaporan pajak di SPT. Tingkat penyerapan aplikasi dan penggunaannya oleh masing-masing account representative ternyata berbeda yang membuat data pemicu di aplikasi approweb secara umum tidak mudah digunakan.

Penelitian ini menyatakan bahwa responden telah mempersepsikan kemudahan atas penggunaan data pemicu di approweb bersifat positif dan tidak signifikan tidak terlepas dari adanya upaya-upaya yang harus dilakukan oleh account representative dalam pengoperasian data pemicu sehingga account representative belum mudah untuk menggunakan data pemicu.

Penelitian-penelitian sebelumnya juga menunjukkan bahwa konstruk persepsi kemudahan penggunaan mempengaruhi persepsi kegunaan, sikap, minat, dan penggunaan sesungguhnya (Jogiyanto, 2007).

Hasil penelitian ini sejalan dengan (Perangin-angin, dkk, 2016) yang menunjukkan bahwa perceived usefullness berpengaruh positif terhadap attitude toward using efaktur, sedangkan perceived ease of use tidak berpengaruh signifikan terhadap atttitude toward using e-Faktur. Dalam hal ini Account representative merasakan kesulitan dalam penggunaan data pemicu apabila menggunakannya dalam pekerjaan sehari-hari.

\section{Persepsi Kerumitan terhadap penggunaan data pemicu di aplikasi approweb.}

Secara statistik hasil penelitian ini menunjukkan bahwa persepsi kerumitan dari responden berpengaruh negatif dan signifikan terhadap penggunaan data pemicu di 
aplikasi approweb. Angka koefisien negatif menunjukkan adanya hubungan yang tidak searah atau terbalik, artinya semakin rumit (complexity) data pemicu di approweb maka semakin rendah penggunaannya oleh account representative. Data responden diperoleh atas jawaban responden untuk kerumitan menunjukkan keselarasan dengan besarnya jawaban responden yang cenderung menjawab kurang setuju dan tidak setuju atau pilihan negatif. Artinya sebagai besar account representative penggunaan data pemicu di approweb tidak menyita waktu dan tidak sulit dipadukan dalam pekerjaan account representative sehari - hari. Y Hipotesis penelitian ini adalah kerumitan (complexity) berpengaruh negatif secara signifikan terhadap penggunaan data pemicu di approweb.

Penelitian ini sejalan dengan penelitian (Mahenda Putra, dkk, 2017), (Satrio, Su'un \& Syamsuri Rahim (2016), (Erika, 2019) tentang pengaruh persepsi kegunaan, kemudahan dan kerumitan terhadap aplikasi e-faktur.

Hasil penelitian ini menunjukkan bahwa kegunaan atau kebermanfaatan berpengaruh positif dan signifikan sedangkan kemudahan berpengaruh positif tidak signifikan dan kerumitan berpengaruh negatif signifikan terhadap data pemicu di aplikasi approweb. Hasil penelitian ini membuktikan teori TAM dari persepsi kebermanfaatan data pemicu di aplikasi approweb bermanfaat bagi account representative.

Hasil penelitian ini menyarankan agar Account Representative dapat terus berlatih menggunakan data pemicu pada aplikasi approweb dan meningkatkan pengetahuan dan keterampilan dalam pengolahan data dalam jumlah yang besar sehingga memudahkan dalam analisa dan pengumpulan data pemicu untuk menghasilkan surat himbauan kepada Wajib Pajak. Bagi instansi Direktorat Jenderal Pajak, terdapat bahwa $69,4 \%$ account representative yang masih belum memahami penggunaan data pemicu di approweb sehingga disarankan untuk memberikan pelatihan secara intensif kepada account representative sehingga mudah untuk digunakan karena sangat penting dalam penggalian potensi pajak. Bagi akademisi, penelitian yang akan datang agar menambahkan variabel-variabel lainnya misalnya kenyamanan, sikap dan minat dalam penggunaan data pemicu di aplikasi approweb

Aminudin, N., \& Putra, D. A. (2017). Langkah-Langkah Taktis Pengembangan EGovernment Untuk Pemerintahan Daerah (PEMDA) Kabupaten Pringsewu. Jurnal TAM (Technology Acceptance Model), 3, 59-66.

Davis, F. D., \& Venkatesh, V. (1996). A critical assessment of potential measurement biases in the technology acceptance model: three experiments. International journal of human-computer studies, 45(1), 19-45.

Erika, W. (2019). ANALISIS PERBANDINGAN METODE TAM (Technology Acceptance Model) DAN UTAUT (Unified of Acceptance and Use of Technology ) TERHADAP PERSEPSI PENGGUNA SISTEM INFORMASI DIGITAL LIBRARY (Studi Kasus: Universitas Pembangunan Panca Budi 
Medan). JURNAL MAHAJANA INFORMASI, 4(1), 78-83. Retrieved from http://e-journal.sari-mutiara.ac.id/index.php/7/article/view/730

Fatmasari, Muhammad Ariandi, 2014, Studi Komparatif Metode Utaut dan Tam Terhadap Penerapan Sistem Informasi Akademik (Studi Kasus: Sistem Informasi Akademik Universitas Bina Darma Palembang), Prosiding SnaPP2014 Sains, Teknologi dan Kesehatan, ISSN: 2089-3582.

Ghozali, I. (2011). Structural Equation Modeling Metode Alternatif Dengan Partial Least Square (PLS) Edisi 3, Badan Penerbit Universitas Diponegoro.

Hamzah, M. F., Ramdani, M. R., \& Muslim, A. H. (2018). Faktor-Faktor Yang Mempengaruhi Kepatuhan Wajib Pajak (Studi Empiris pada KPP Pratama Kabupaten Sidrap). journal of institution and sharia finance, 1(1).

Jogiyanto, H. M. (2007). Model Kesuksesan Sistem Teknologi Informasi. Yogyakarta: Penerbit Andi.

Mahendra, A Reza, dan Affandy. D. Poernawan. (2013). Faktor-Faktor yang mempengaruhi Minat Pemanfaatan Sistem Informasi Pengelola Keuangan Daerah (SIPKD): Studi Kasus Pada Pemerintah Kota Blitar. Jurnal Akuntansi Fakultas Ekonomi Universitas Brawijaya, h : 1-23.

Perangin-angin, W. A., Respati, A. D., \& Kusumawati, M. D. (2018). Pengaruh perceived usefulness dan perceived ease of use terhadap attitude toward using e-faktur. Jurnal Riset Ekonomi dan Manajemen, 16(2), 307-322.

Priyambada, B., Kusyanti, A., \& Herlambang, A. D. (2017). Analisis Penerimaan SIDJP Menggunakan Technology Acceptance Model (TAM) Pada KPP Pratama Mojokerto. Jurnal Pengembangan Teknologi Informasi dan Ilmu Komputer eISSN, 2548, 964X.

Satrio, D. B., Su'un, M., \& Rahim, S. (2017). Pengaruh Persepsi Kegunaan, Kemudahan, dan Kerumitan terhadap Aplikasi E-Faktur di Makassar. Assets: Jurnal Ekonomi, Manajemen dan Akuntansi, 7(2), 183-196.

Sayekti, F., \& Putarta, P. (2016). Penerapan Technology Acceptance Model (TAM) dalam Pengujian Model Penerimaan Sistem Informasi Keuangan Daerah. Jurnal Manajemen Teori dan Terapan | Journal of Theory and Applied Management, 9(3).

Sugiyono, D. (2010). Metode penelitian kuantitatif dan R\&D. Bandung: Alfabeta. 